\title{
TRIM33/RET Fusion Protein
}

National Cancer Institute

\section{Source}

National Cancer Institute. TRIM33/RET Fusion Protein. NCI Thesaurus. Code C99854.

A fusion protein encoded by the TRIM33/RET fusion gene. This protein is comprised of $964 \mathrm{~N}$-terminal amino acids of the E3 ubiquitin-protein ligase TRIM33 protein, including the RING finger, B-box, and PHD domains, fused with most of the C-terminal cytoplasmic domain of the proto-oncogene tyrosine-protein kinase receptor Ret protein, including the tyrosine kinase domain. 